Article

\title{
Energy Management Strategy Based on Multiple Operating States for a Photovoltaic/Fuel Cell/Energy Storage DC Microgrid
}

\author{
Ying Han, Weirong Chen and Qi Li * \\ School of Electrical Engineering, Southwest Jiaotong University, Chengdu 610031, China; \\ hanying@my.swjtu.edu.com (Y.H.); wrchen@swjtu.edu.cn (W.C.) \\ * Correspondence: liqi0800@163.com; Tel.: +86-28-8760-3332 \\ Academic Editor: Ying-Yi Hong \\ Received: 10 September 2016; Accepted: 13 January 2017; Published: 21 January 2017
}

\begin{abstract}
It is a great challenge for DC microgrids with stochastic renewable sources and volatility loads to achieve better operation performance. This study proposes an energy management strategy based on multiple operating states for a DC microgrid, which is comprised of a photovoltaic (PV) array, a proton exchange membrane fuel cell (PEMFC) system, and a battery bank. This proposed strategy can share the power properly and keep the bus voltage steady under different operating states (the state of charge (SOC) of the battery bank, loading conditions, and PV array output power). In addition, a microgrids test platform is established. In order to verify the effectiveness of the proposed energy management strategy, the strategy is implemented in a hardware system and experimentally tested under different operating states. The experimental results illustrate the good performance of the proposed control strategy for the DC microgrid under different scenarios of power generation and load demand.
\end{abstract}

Keywords: DC microgrid; energy management strategy; multiple operating states; photovoltaic (PV) array; proton exchange membrane fuel cell (PEMFC); battery bank

\section{Introduction}

Increasing demand for electrical power and severe environmental problems caused by fossil energy justify the need for developing a green, renewable power generation system. To make the best use of renewable energy, microgrids have been widely studied and play an important role in the future smart power system [1-3]. Microgrids are generally defined as a combination of different distributed generations, energy storage systems, loads, supervisory control, protection, and energy management systems. Compared with a single DG unit, microgrids show higher reliability, flexibility, and efficiency $[4,5]$. According to different types of bus, micro grids can be divided into AC microgrids, DC microgrids, and AC/DC microgrids. Among them, AC microgrids are the most widely microgrid type. AC microgrids can operate either in the grid-connected or islanded mode; and several control techniques have been developed to perform active and reactive power sharing, frequency and voltage regulation, and power quality disturbance compensation [6-8].

Nowadays, DC microgrids are continuously demonstrating the advantages over AC microgrids, and have become an increasingly popular solution for small-scale power systems in close physical proximity $[9,10]$, due to the less energy loss from power transmission lines over long distances. In DC microgrids, the distributed generators (e.g., photovoltaic (PV), fuel cells (FCs)), energy storage systems (e.g., batteries, supercapacitors), and loads (e.g., electronics, chargers, LED lighting) are connected without DC/AC conversion, which contributes to a higher system efficiency, higher system stability, and lower system cost. Fruthermore, DC microgrids are not afflicted with frequency synchronization, 
reactive power flow, and other power quality issues that are common in AC systems [11-13]. Therefore, the DC microgrids show great potential in building electrical systems, datacom centers, and plug-in hybrid electric vehicles in the future [14-17].

Energy management and optimal control of microgrids are the prerequisites of continued stable and economically efficient operation [17]. At present, a large number of studies have been performed on PV/Battery DC microgrids and PV/Wind/Battery DC microgrids $[18,19]$. FCs are characterized as low-polluting and high efficiency systems that have low maintenance costs, but they are still considered to be developing technologies [20]. With the development of hydrogen utilization technology, hydrogen DC microgrids have been found in several studies, which rely on batteries for short-term energy storage whilst FC works as a long-term energy storage system. Various hybrid topologies and control methods have been proposed in [21-26]. Because of the stochastic output power of PV arrays and great wind generators fluctuation under varying weather conditions [27], controlling the power flow between FC systems and energy storage systems is a huge challenge for energy management strategy. Many control methods have been proposed in the literature for energy management of DC microgrids. Valverde et al. [21] proposed a voltage control method with power dynamic limitation to prevent fuel starvation problem and improve performance. An on-off switch threshold control method depending on the battery state of charge (SOC) is used to manage the operation of the FC in Thounthong et al. [22]. Brka et al. [23] presents a predictive power management strategy, which predicts the load demand and the output power of renewable energy sources to switch the FC and batteries. In order to maintain the DC bus voltage and limit the battery and FC currents slope, an energy management strategy based on model predictive control is implemented in Amin et al. [24] and. Valverde et al. [25]. Bizon et al. [26] proposed the load following control based on the average power flows balance and maximum efficiency point tracking based on extremum seeking control scheme to reduce the battery stack at minimum and operate the FC stack efficiently for the FC/battery hybrid power source. These energy management strategies mentioned above have been proven effective in dealing with power balance problem. Nowadays, few studies have developed a real hydrogen DC microgrid system due to technical constraints, and these approaches are generally very computationally demanding and place greater demands on the computing performance of the controller. Meanwhile, these proposed strategies have not adequately considered the coordination control of multiple control objectives and the operating efficiency for the FC. Since FCs have higher generation cost compared with other distributed generation types, FC efficiency will have a great influence on system efficiency and economy [28].

To address the aforementioned issues, we will focus on the energy management strategy for the $\mathrm{PV} / \mathrm{FC} /$ energy storage DC microgrid in this paper. An experimental system is built for this microgrid, where the primary and auxiliary sources are PV array and FC generation system respectively and a battery bank works as an energy storage device. In order to improve the efficiency of distributed generators, prevent the FC output power from fluctuating frequently, and maintain the battery SOC within a suitable range, an efficient optimal energy management strategy is employed in this system to control the multiple objectives coordinately. The proposed strategy is designed by 13 operating states depending on the SOC of battery bank, the system's net demand power, and the optimal working points of distributed generations. The proposed power management strategy is evaluated in this DC microgrid under different operating conditions to prove the correctness of the control strategy.

This paper is organized as follows. Section 2 describes a configuration of DC microgrid system and its major component. Section 3 proposes an efficient optimal energy management strategy based on multiple operating states. Section 4 details results and discussions. Finally, the main conclusions are drawn in Section 5. 


\section{DC Microgrid Description and Experimental Set-Up}

\subsection{Microgrid Configuration}

Figure 1 shows the DC microgrid in this work, which is consisted of a PV array simulator, a proton exchange membrane fuel cell (PEMFC) system and a battery bank connected in parallel by DC/DC converters, a DC electronic load emulates demand profiles, and an energy management system is built based on a data acquisition (DAQ) card (ADLINK Technology (China) Co., Inc, Shanghai, China) and serial communication RS232 (UTEK Technology (Shenzhen) Co., Inc, Shengzhen, China) of PC. In the proposed DC microgrid, a PV array and an FC system work as the primary and auxiliary sources respectively while battery bank is the energy storing elements. The PV array simulator works in maximum power point (MPP), and the FC system and battery bank are controlled by the energy management system. The parameters of the microgrid entities are listed in Table 1.

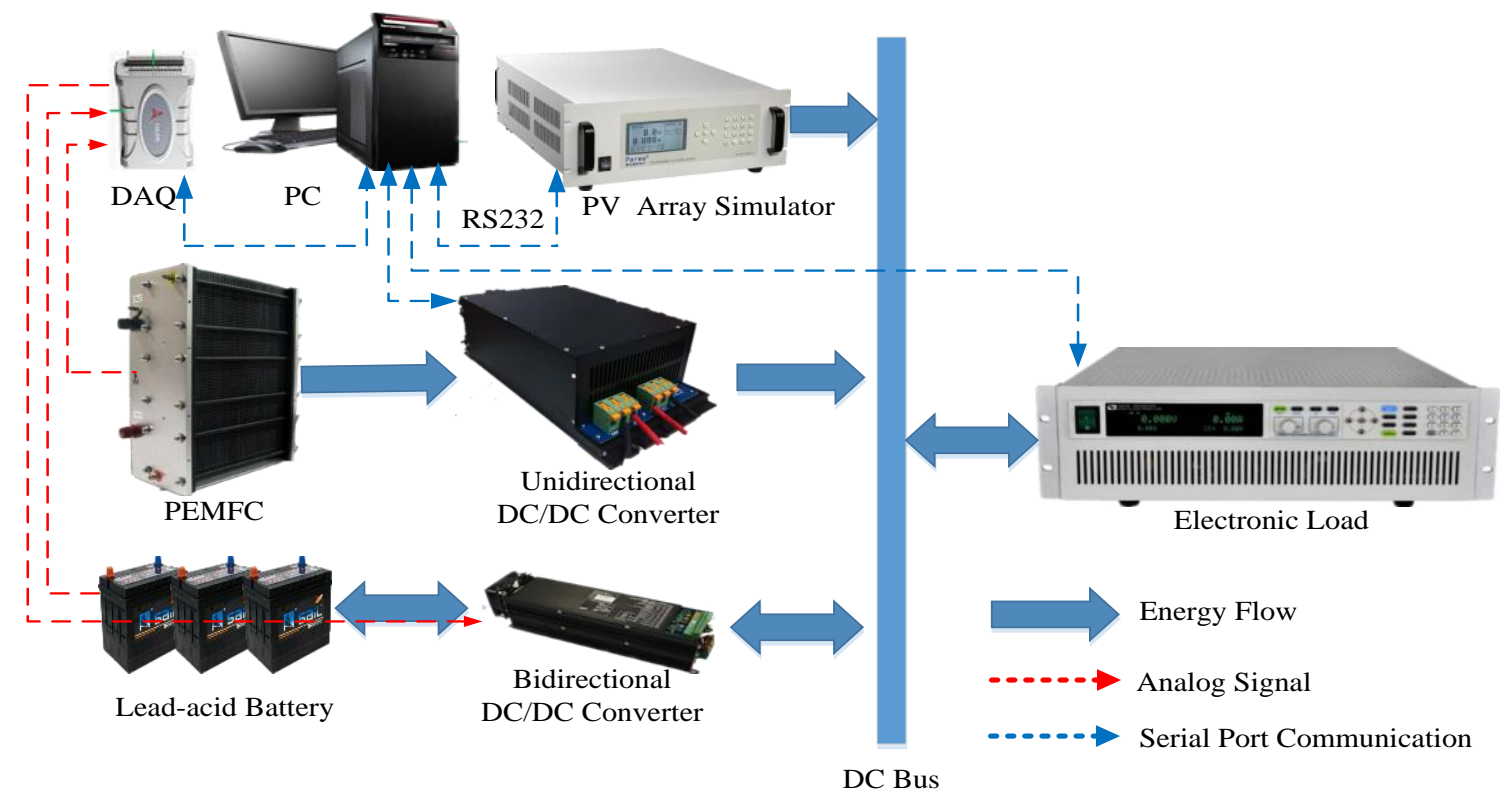

Figure 1. Configuration of the proposed DC microgrid.

Table 1. Parameters of the proposed DC microgrid.

\begin{tabular}{clc}
\hline Subsystems & \multicolumn{1}{c}{ Descriptions } & Values \\
\hline \multirow{3}{*}{ PV array simulator } & open-circuit voltage & $50 \mathrm{~V}$ \\
& voltage of the maximum power & $36 \mathrm{~V}$ \\
& short-circuit current & $30 \mathrm{~A}$ \\
& current of the maximum power & $28 \mathrm{~A}$ \\
& rated power & $1000 \mathrm{~W}$ \\
\hline \multirow{2}{*}{ Fuel cell } & rated power & $1000 \mathrm{~W}$ \\
& voltage range & $32-34 \mathrm{~V}$ \\
& maximum current & $32 \mathrm{~A}$ \\
& maximum temperature & $65{ }^{\circ} \mathrm{C}$ \\
\hline \multirow{3}{*}{ Battery bank } & rated voltage & $12 \times 3 \mathrm{~V}$ \\
& rated capacity & $36 \mathrm{Ah}$ \\
& set numbers & $3 \mathrm{series}$ \\
\hline \multirow{2}{*}{ Load } & DC bus voltage & $60 \mathrm{~V}$ \\
& rated power & $1500 \mathrm{~W}$ \\
\hline
\end{tabular}




\subsection{Photovoltaic Array Simulator}

In this paper, the PV array has two operation modes: MPPT mode and constant voltage mode. On the premise of making full use of renewable energy, PV array keeps the maximum output power with the change of environment in most cases. Because of the limitations on PV array availability in a laboratory environment, a PV array simulator is used for emulating the proposed microgrid system tested platform.

In order to verify the correction of PV array simulator output characteristic, the comparison I-V and P-V curves of theoretical model and PV array simulator are shown in Figure 2, and the detailed description about the modeling of the PV model can be found in [29]. It can be concluded that the output characteristic of the PV array simulator is consistent with the theoretical model due to the low errors which are less than $2 \%$. Therefore, the PV array simulator is effective to use in the established DC microgrid text platform.

(a)

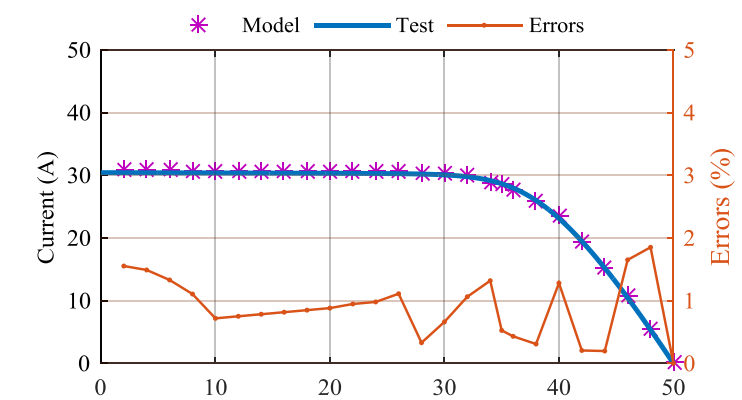

(b)

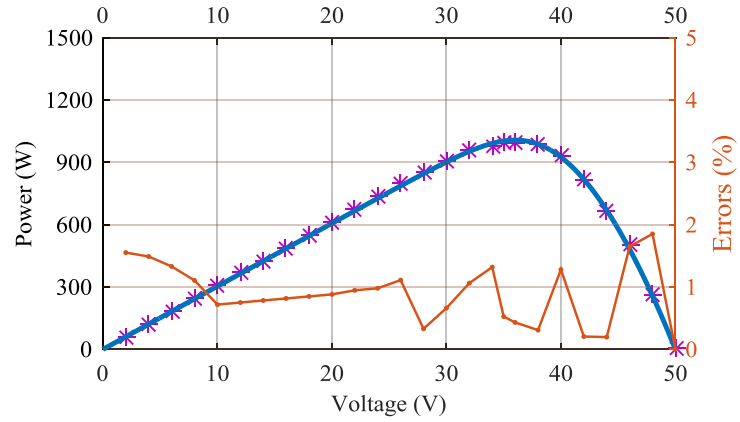

Figure 2. The comparison of photovoltaic (PV) array simulator and theoretical model. (a) The relationship between voltage and current; (b) The relationship between voltage and power.

\subsection{Proton Exchange Membrane Fuel Cell Generation System}

In this study, the PEMFC generation system has three components: PEMFC stack, FC subsystem and the unidirectional DC/DC converter, as shown in Figure 3. The PEMFC stack is a 1000 W PEMFC stack manufactured by Horizon FC technologies. The rated power of the stack is $1000 \mathrm{~W}$ and the output voltage varies between 32 and $45 \mathrm{~V}$ with maximum current $35 \mathrm{~A}$. The output characteristic curve of FC stack is displayed in Figure 4. The subsystem consists of an air-cooled stack, blower, $\mathrm{H}_{2}$ pressure regulator and valves, controller for interfacing with the main controller (startup and shutdown control, optimal temperature control), and protections (over temperature, over current, and under voltage). Because the FC output is unregulated, which means the stack voltage drops with the increasing output current, and a unidirectional DC/DC converter is required to maintain a steady bus voltage. In this work, the unidirectional DC/DC converter requires an output voltage reference and a maximum output current reference.

In order to improve fuel economy, it is necessary that the FC works at the maximum operation efficiency point. The FC efficiency is inversely proportional to the output power, while the efficiency of FC converter is proportional to output power. Therefore, the combined efficiency curve of the PEMFC generation unit is shown in Figure 5, and the peak of the curve represents the optimal operating point. 


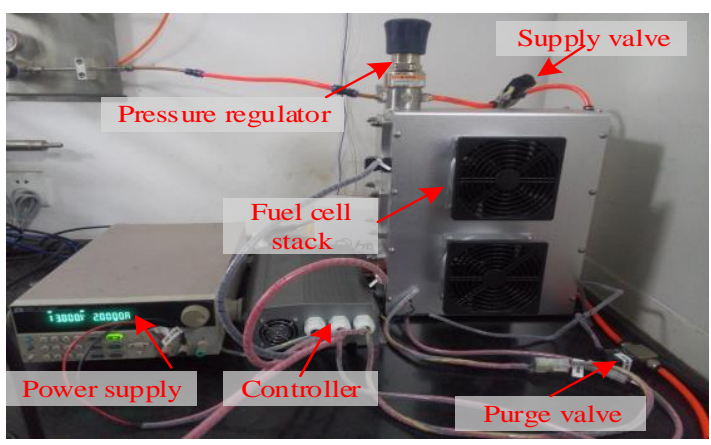

(a)

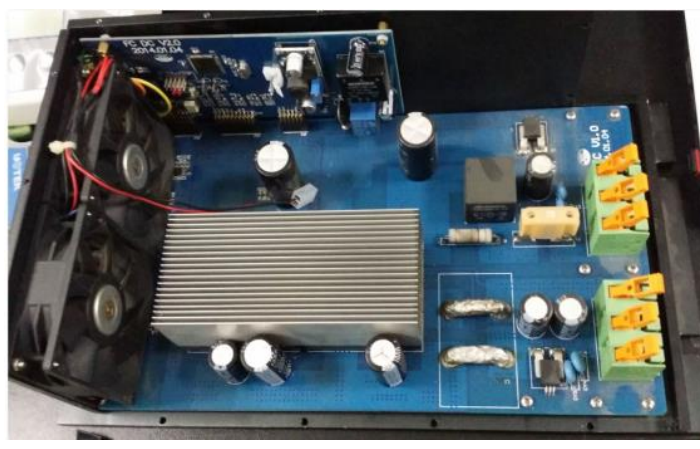

(b)

Figure 3. Proton exchange membrane fuel cell (PEMFC) generation system. (a) The fuel cell stack and its auxiliary; (b) the fuel cell's DC/DC converter.

(a)

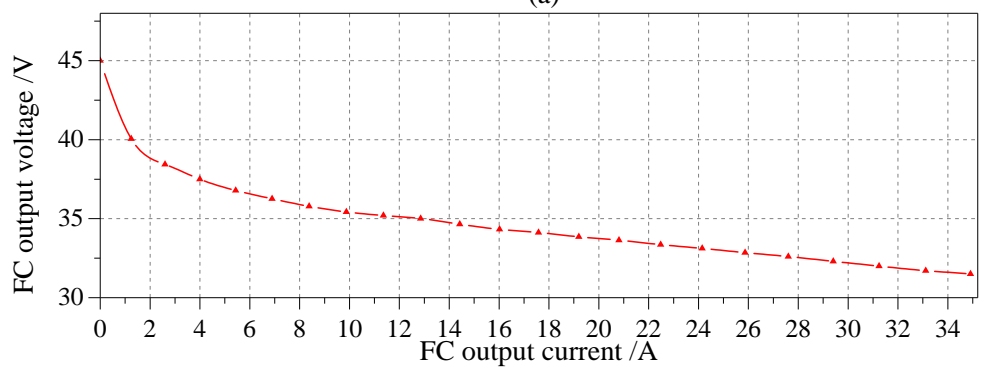

(b)

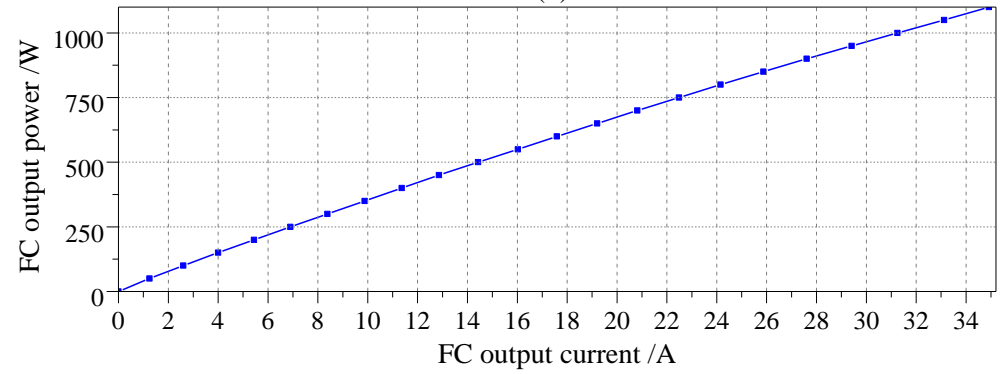

Figure 4. PEMFC voltage and power polarization curve. (a) The relationship between voltage and current; (b) The relationship between current and power.

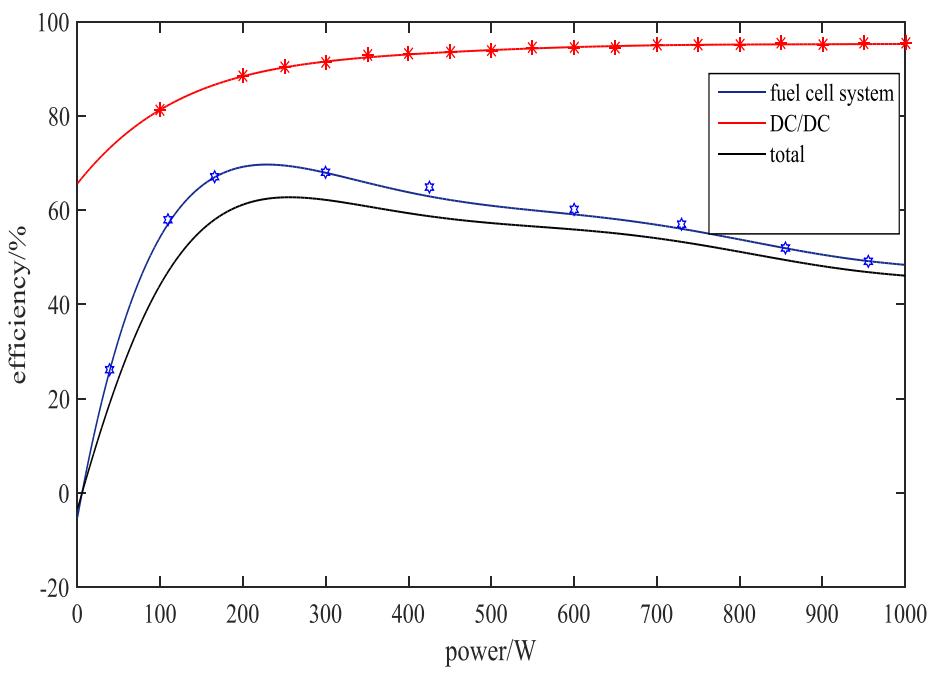

Figure 5. PEMFC generation system combined efficiency. 


\subsection{Battery Energy Storage System}

In this paper, the energy storage system of the DC microgrid is a battery bank, which is composed of three lead-acid batteries in parallel with rated voltage $36 \mathrm{~V}$ and rated capacity $36 \mathrm{Ah}$. The SOC is defined as the remaining capacity of battery. In order to avoid over charging/discharging to protect the battery bank from damage, SOC is regarded as an important input variable of the energy management system. The SOC of battery bank can be calculated as Equation (1), where $S O C_{0}$ is the initial SOC, $Q_{\max }$ is the battery bank's normal capacity (Ah), and $i$ is the battery current.

$$
\operatorname{SOC}(t)=S_{0}+\left(1 / Q_{\max }\right) \cdot \int i(t) \mathrm{d} t \cdot 100 \%
$$

A Zahn DC15036F-S DC/DC (Zahn Electronics Inc., Franksville, WI, USA) converter is used to regulate the power delivered by the battery bank to the bus. This half-bridge converter has bidirectional current-control capabilities. The converter works in buck mode during charging process and boost mode during discharge process. The acceptable output current range is $36 \mathrm{~A}$, and the maximum output power is $2880 \mathrm{~W}$.

\section{Energy Management Strategy Based on Multiple Operating States}

For a DC microgrid, the energy management strategy has a great effect on the fuel economy, dynamic performance, and service life of distributed generators [22]. The primary goal of the energy management strategy for the proposed DC microgrid is to ensure that the injected energy to load and the consumed energy are equal. In addition, extending the life of the distributed generators and reducing the system cost are also crucial control goals. Specifically, the proposed energy management strategy should fulfil the following objectives:

(1) To maintain the stability of the DC bus voltage.

(2) To keep the PV array simulator working at the maximum output power under varying environment states.

(3) To protect the battery bank from deep discharging and overcharging.

(4) To avoid the PEMFC system output power from fluctuations frequently.

(5) To reduce the hydrogen consumption by keeping the PEMFC system and the battery bank works in the optimal efficiency point as much as possible.

In this paper, an efficient optimal energy management strategy based on multiple operating states is proposed to control the multiple objectives coordinately. In the normal working condition, the PV array works in MPPT mode mostly, the FC system and the battery bank are controlled by the proposed strategy to distribute properly to balance the demand power. The proposed strategy is designed based on multiple operating states, which are decided by the battery SOC states, the system's net demand power, and the limit points of the distributed generations.

The SOC of the battery bank is divided into three states: high SOC, normal SOC, and low SOC. Furthermore, in order to avoid the operating state of the battery bank from switching frequently, the changes between different states based on two hysteresis cycles are designed using four SOC levels $\left(S O C_{\min }\right.$ and $S O C_{\max }$ are the lower and the upper limits of $S O C$, and $S O C_{n o m 1}$ and $S O C_{n o m}$ are the upper and lower bounds of the preferred zone of battery SOC), as shown in Figure 6.

In this work, the FC and battery bank should provide power difference between the load power and the output power of the PV array based on the proposed energy management strategy. In order to keep the battery SOC in a suitable range, the system's net demand power is defined as $P_{\text {net }}$ in this strategy. In the low SOC state, the FC system and battery bank should charge the battery to increase the battery SOC as well as provide the system's demand power; in the high SOC state, the FC system and battery bank should discharge the battery to decrease the battery SOC as well as provide the 
system's demand power. $P_{\text {net }}$ can be real-time calculated under different SOC state, which is expressed as Equation (2).

$$
P_{\text {net }}(t)=\left\{\begin{array}{cl}
P_{\text {load }}(t)-P_{p v}(t)+P_{\text {batopt }} & \text { Low SOC } \\
P_{\text {load }}(t)-P_{p v}(t) & \text { Normal SOC } \\
P_{\text {load }}(t)-P_{p v}(t)-P_{\text {batopt }} & \text { High SOC }
\end{array}\right.
$$

where, $P_{\text {load }}$ and $P_{p v}$ are the real-time measured load demand power and the output power of PV array respectively, $P_{\text {batopt }}$ is the optimal output power of the battery bank.

The limit points of the distributed generators are determined based on the optimal working points of distributed generations: the maximum, minimum, and optimum values of FC system output power $\left(P_{f c m a x}, P_{f c m i n}, P_{f c o p t}\right)$ and the maximum and optimum efficiency values of battery bank power $\left(P_{\text {batmax }}\right.$ and $\left.P_{\text {batopt }}\right)$.

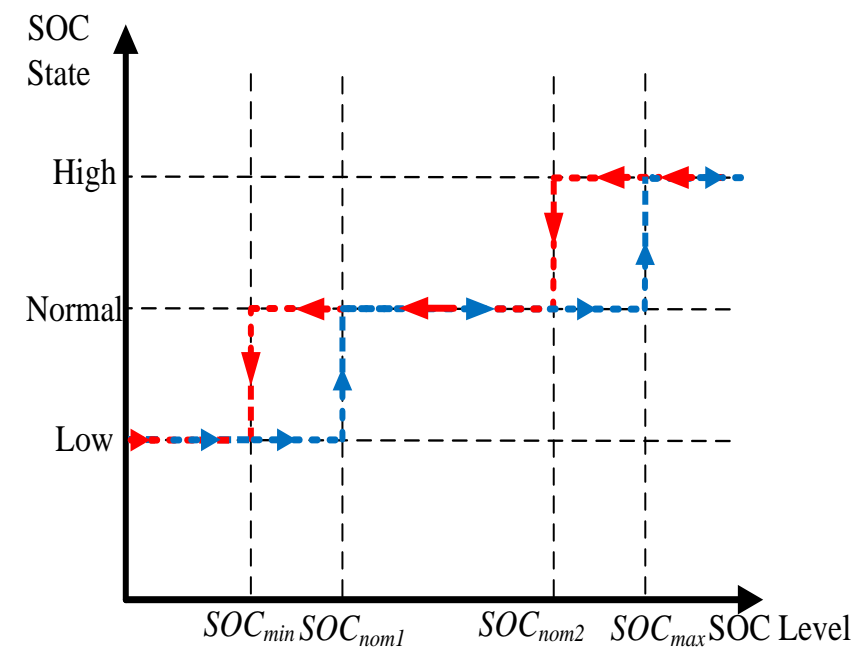

Figure 6. Hysteresis cycles for SOC states of battery bank.

Based on the above analysis, the system's operating state is divided into 13 operating states depending on the SOC of battery bank and the system's net demand power $P_{n e t}$. Under different operating states, the FC reference power $P_{f_{c}}{ }^{*}(t)$ can be calculated with hysteresis characteristic as shown in Table 2.

Table 2. Control decisions based on operating states.

\begin{tabular}{|c|c|c|c|}
\hline SOC State & State & Net Demand Power Characteristics & $P_{f_{c}} *(t)$ \\
\hline \multirow{5}{*}{ Low SOC } & 1 & $P_{\text {net }}(t)<P_{\text {fcopt }}$ & $P_{\text {fcopt }}$ \\
\hline & 2 & $\left(P_{f_{c}}^{*}(t-\Delta t)=P_{\text {fcopt }}\right) \&\left(P_{\text {net }}(t)<P_{\text {batopt }}\right)$ & $P_{\text {fcopt }}$ \\
\hline & 3 & $P_{\text {net }}(t)>P_{f c m a x}$ & $P_{f c m a x}$ \\
\hline & 4 & $\left(P_{f_{c}}{ }^{*}(t-\Delta t)=P_{f c m a x}\right) \&\left(P_{\text {net }}(t)>P_{\text {batopt }}+P_{\text {fcopt }}\right)$ & $P_{f c m a x}$ \\
\hline & 5 & otherwise & $P_{\text {fcopt }}+P_{\text {batopt }}$ \\
\hline \multirow{4}{*}{ Normal SOC } & 6 & $P_{\text {net }}(t)<P_{\text {fcopt }}$ & $P_{\text {fcopt }}$ \\
\hline & 7 & $\left(P_{f c}^{*}(t-\Delta t)=P_{f c o p t}\right) \&\left(P_{\text {net }}<P_{\text {batopt }}\right)$ & $P_{\text {fcopt }}$ \\
\hline & 8 & $P_{\text {net }}(t)>P_{f c m a x}$ & $P_{f c \max }$ \\
\hline & 9 & otherwise & $P_{n e t}(t)$ \\
\hline \multirow{4}{*}{ High SOC } & 10 & $P_{\text {net }}(t)<P_{f c m i n}$ & $P_{f c m i n}$ \\
\hline & 11 & $\left(P_{f c}^{*}(t-\Delta t)=P_{f c m i n}\right) \&\left(P_{\text {net }}(t)<P_{f c o p t}\right)$ & $P_{f c m i n}$ \\
\hline & 12 & $P_{\text {net }}(t)>P_{\text {fcmax }}+P_{\text {batopt }}$ & $P_{f c m a x}$ \\
\hline & 13 & otherwise & $P_{\text {net }}(t)-P_{\text {batopt }}$ \\
\hline
\end{tabular}




\section{(1) Low SOC}

In order to increase the SOC to a suitable range, the battery bank is required to work in the charging mode as much as possible. In this case, the proposed energy management strategy distributes the FC reference power based on hysteresis cycles, and the PEMFC system output power operates at three constant levels to avoid fluctuating frequently.

\section{(2) Normal SOC}

In second case, the battery bank tries to keep the SOC in a suitable range. Based on the energy management strategy, the FC system will work mostly at the optimal efficiency point to power the low net demand power, and work at the command of net demand power in other situations.

\section{(3) High SOC}

In this case, the battery bank works in optimal efficiency discharging mode to reach a suitable level. The FC system will work mostly at the minimum power to reduce the hydrogen consumption. When the net demand power increases, the FC will operate to provide a higher output power point.

Furthermore, in order to overcome the extreme situation, the energy management strategy needs to be especially considerate of situations such as a full battery or an empty battery. If the battery SOC is very high, the battery will stop charging; if the maximum output power of the PV array $P_{p v}>P_{\text {load }}+P_{f c m i n}$ at the same time, the FC system stops working, the PV converter will turn to the constant voltage mode from MPPT mode, and provide the load power. Otherwise, if the battery is empty, the battery will stop discharging; and if the maximum output power of the PV array $P_{p v}<P_{\text {load }}-P_{f c m a x}$ concurrently, the sensitive load should be removed from this system.

The PV array, the FC system and the battery bank play different roles in this DC microgrid based on the efficient optimal energy management strategy. In order to make full use of renewable energy, the PV array keeps working in MPPT mode mostly in the normal operating condition; and turn to the constant voltage mode in the extreme operating condition. The charging and discharging of the battery bank are controlled by the energy management strategy to realize the reasonable power distribution between the FC and battery. Meanwhile, the FC converter which works at constant voltage mode to maintain the stability of the DC bus voltage and the balance of the power flow. Because the output of the energy management system (EMS) is the FC reference power $P_{f_{c}}{ }^{*}$, the battery reference output power $P_{b a t}{ }^{*}$ is the difference between the load power $P_{\text {load }}$ and the FC reference power $P_{f c}{ }^{*}$. Then, the battery reference power $P_{b a t}{ }^{*}$ is divided by the bus voltage or battery voltage to obtain the battery bank reference current $I_{b a t}{ }^{*}$. Finally, a current regulator adjusts discharging or charging current to this value to control the charging and discharging of battery bank. Figure 7 shows the control structure of the DC microgrid system. 

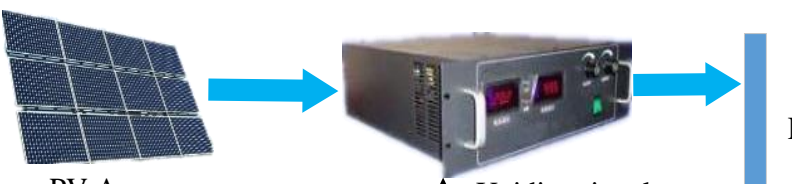

DC bus

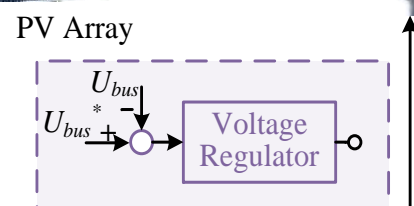

Unidirectional

DC/DC Converter
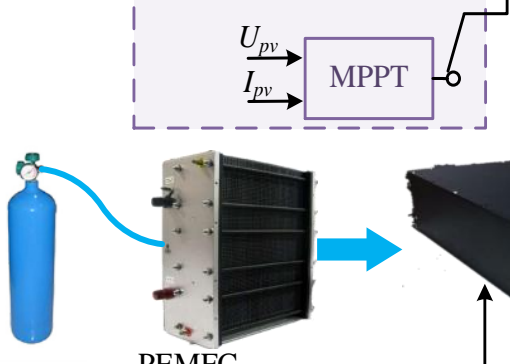

PEMFC

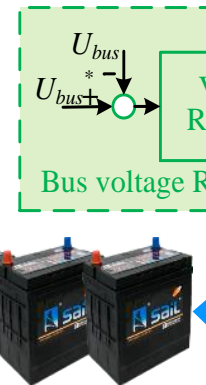

Battery Bank

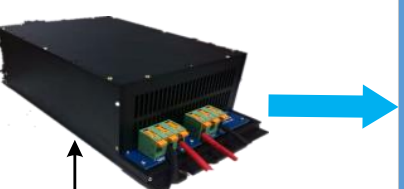

Unidirectional

DC/DC Converter

Voltage

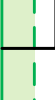

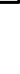<smiles>[13CH]=[13CH][Te]</smiles>

$$
-----1
$$
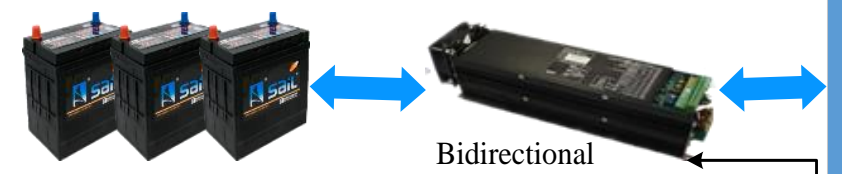

Bidirectional DC/DC Converter

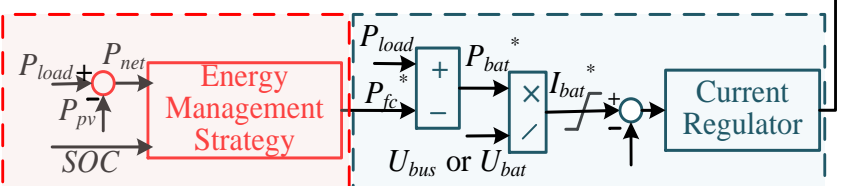

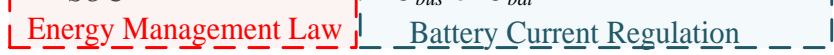

Figure 7. Control structure of the DC microgrid system.

\section{Results and Discussions}

In this paper, a PV/FC/energy storage DC microgrid is set up, as shown in Figure 8, and the control parameters are shown in Table 3. In order to authenticate the efficient optimal energy management strategy under different initial battery SOC $(25 \%, 60 \%$ and $95 \%)$, the proposed energy management system and the converters' controller are built within the LabVIEW environment and executed with DAQ card and RS232.

Table 3. Control parameters of the energy management system.

\begin{tabular}{cccc}
\hline Description & Values & Description & Values \\
\hline$S O C_{\text {min }}$ & $30 \%$ & $P_{f c m i n}$ & $100 \mathrm{~W}$ \\
$S O C_{\text {nom } 1}$ & $40 \%$ & $P_{f c o p t}$ & $230 \mathrm{~W}$ \\
$S O C_{\text {nom } 2}$ & $70 \%$ & $P_{f c m a x}$ & $1000 \mathrm{~W}$ \\
$S O C_{\max }$ & $80 \%$ & $P_{\text {batopt }}$ & $400 \mathrm{~W}$ \\
\hline
\end{tabular}




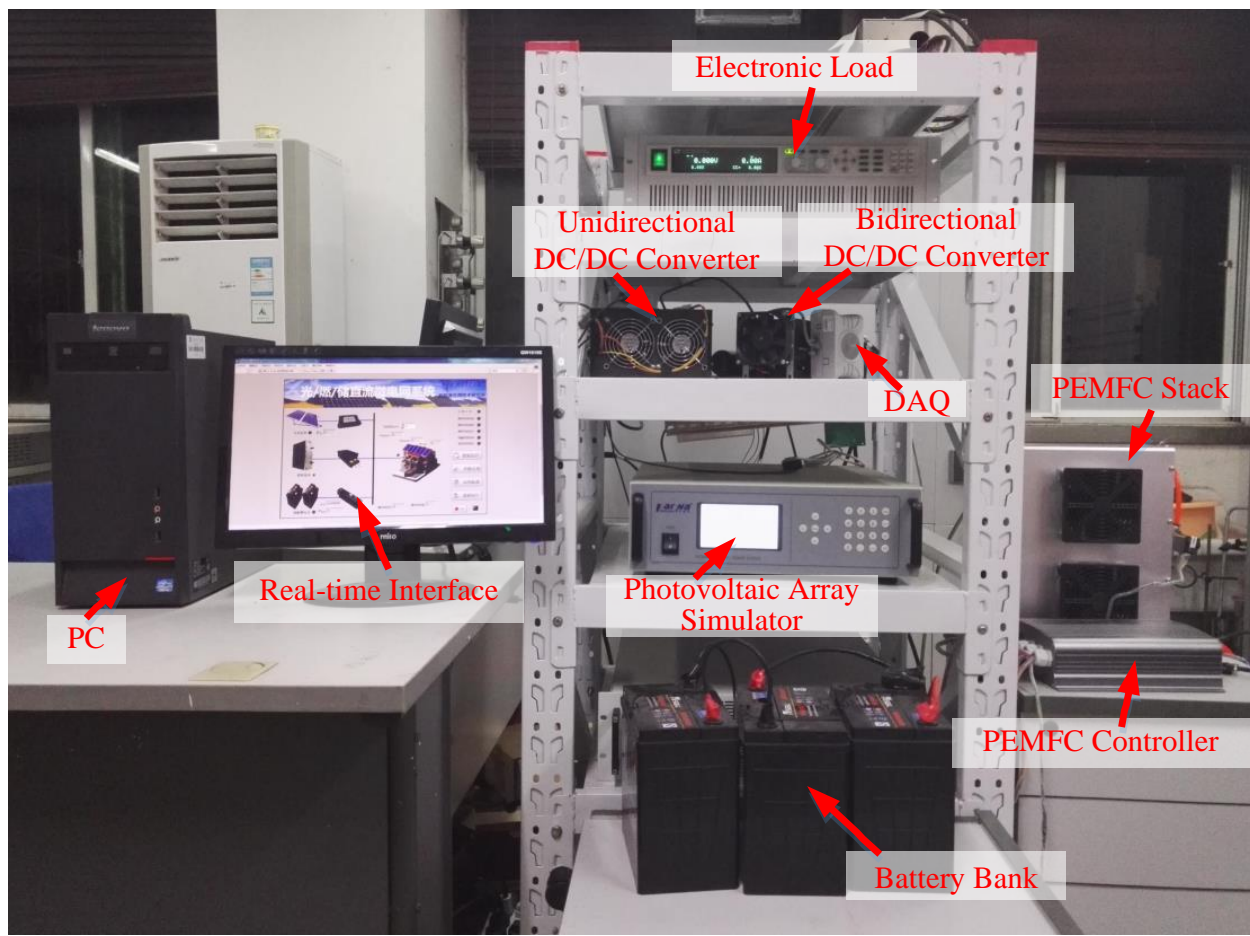

Figure 8. General view of the experimental test setup.

\subsection{Case I: Experiment with Initial State of Charge of 25\%}

In Case I, the battery bank works with a low SOC of $25 \%$, and the energy management system works in state 1 state 5. Because of the strong fluctuation in the PV array output power in a cloudy scenario, the output power of FC is set into three constant levels based on hysteresis cycles. In order to increase the SOC to a suitable range, the battery bank will be charged as much as possible. The distributed generations output powers and the load power are given in Figure 9, and the bus voltage and SOC of the battery bank are presented in Figure 10. The results can be observed that: the FC generation system can work smoothly in three power levels; the battery bank tries to be charged at a high rate, and the SOC of battery bank increases to $34 \%$ after $5000 \mathrm{~s}$. The fluctuation range of bus voltage is less than $1 \mathrm{~V}$.

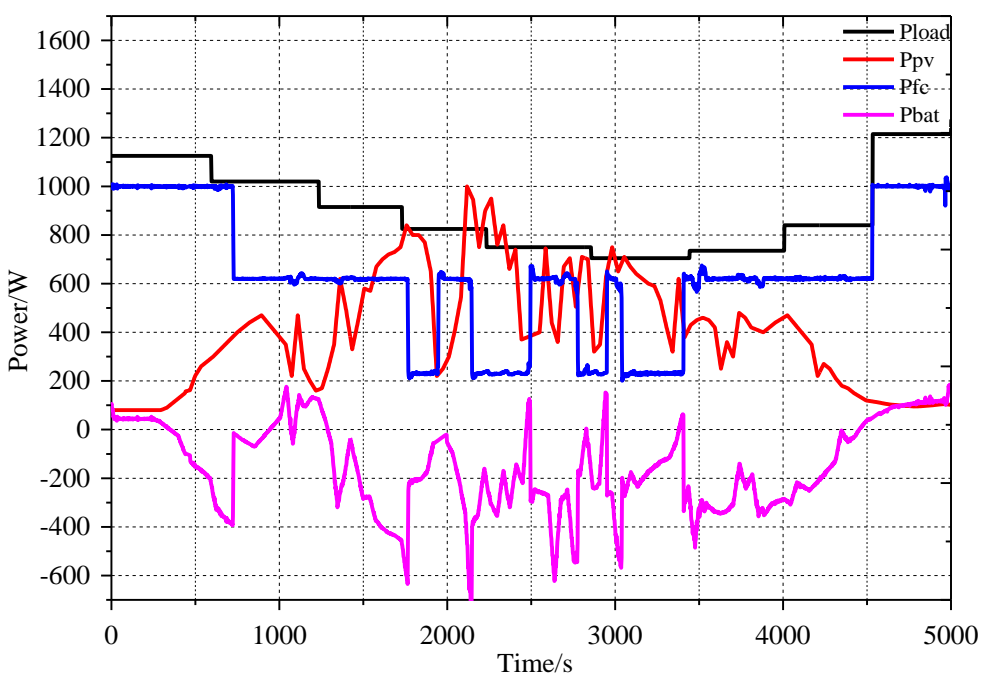

Figure 9. Power flow of the DC microgrid with initial SOC at $25 \%$. 


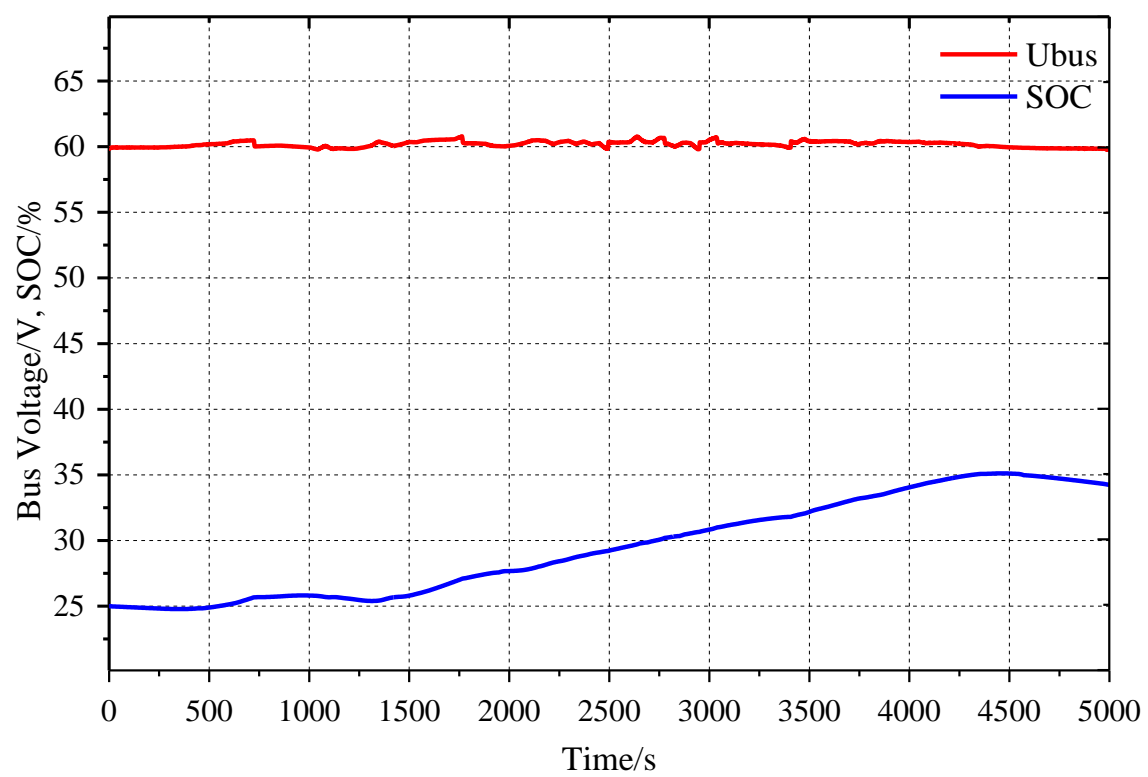

Figure 10. The bus voltage and SOC of the battery bank in Case I.

\subsection{Case II: Experiment with Initial State of Charge of $60 \%$}

In Case II, the initial SOC of battery bank is $60 \%$, the energy management system works in state 6 state 9, which means that the battery bank begins to work with a normal SOC state. Therefore, the FC system will work mostly at the optimum point to power the low net demand power, and work at the command of net demand power in other situations. Meanwhile, the charging and discharging of the battery bank are controlled to keep the SOC in a suitable range by the energy management system. Figure 11 shows the distributed generations' output powers and the load power respectively, and Figure 12 presents the bus voltage and SOC of the battery bank. The results show that the FC system works mostly at the optimal efficiency point, and the fluctuation range of SOC is less than $3 \%$ in the whole working period.

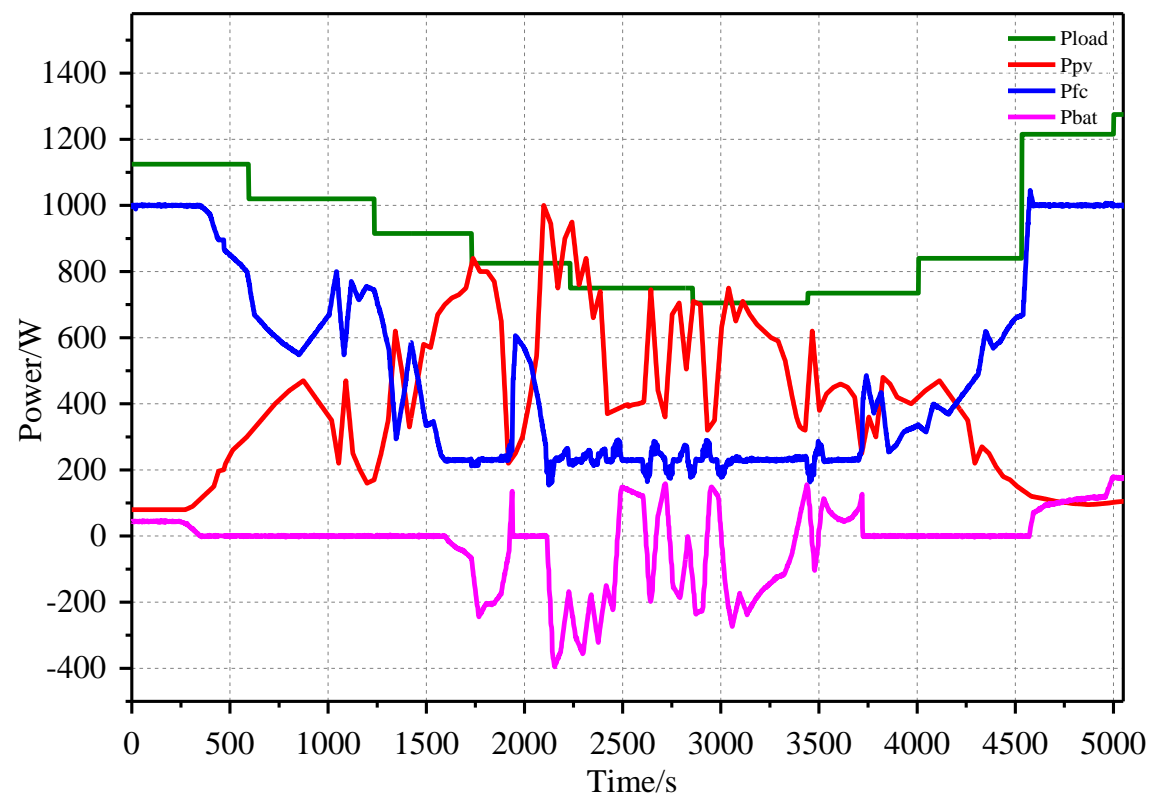

Figure 11. Power flow of the DC microgrid with initial SOC at $60 \%$. 


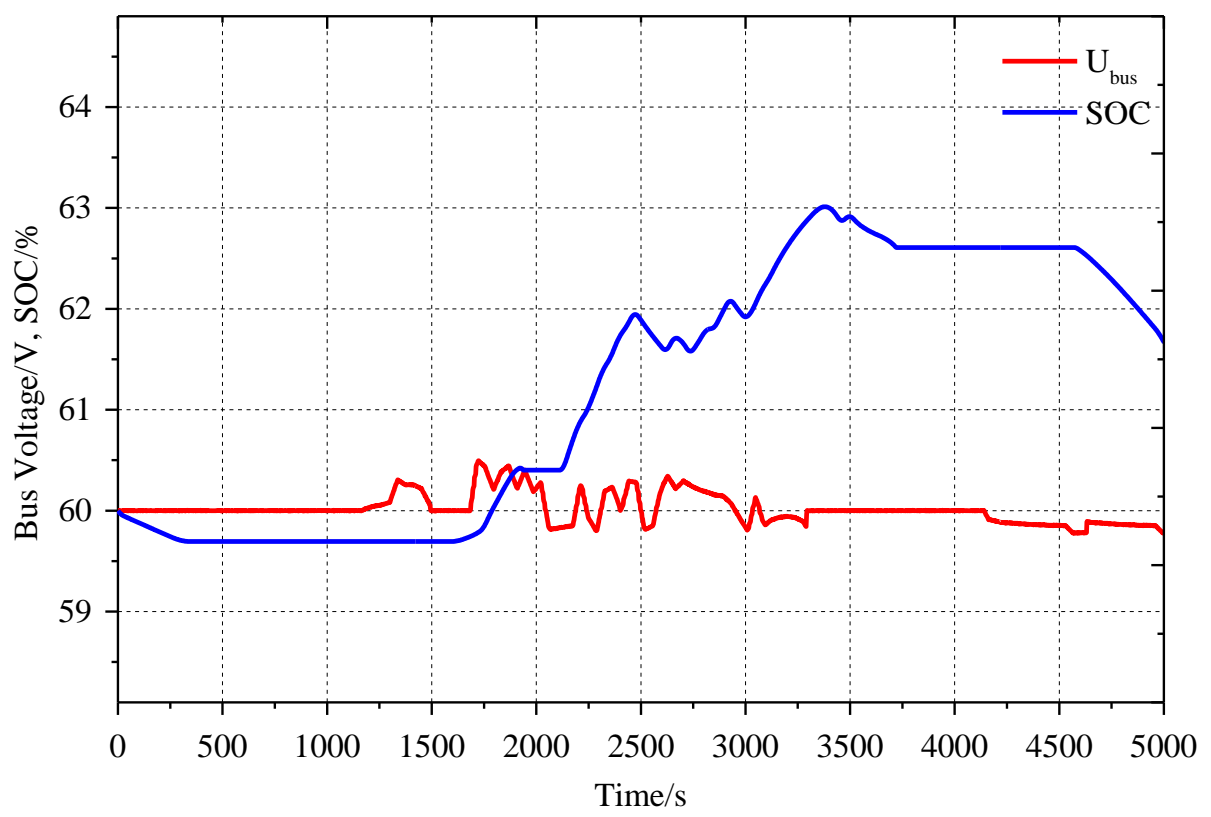

Figure 12. The bus voltage and SOC of the battery bank in Case II.

\subsection{Case III: Experiment with Initial State of Charge of $95 \%$}

In Case III, the initial SOC of battery bank is $95 \%$, and the energy management system works in state 10 state 13. Therefore, the battery bank should be discharged to reach a suitable level. The FC system will work mostly at the minimum power to reduce the hydrogen consumption and work at the command of load power when the net demand power is high. The distributed generations output powers and the load power are seen in Figure 13, and the bus voltage and SOC of the battery bank is presented in Figure 14. It is evident that the FC system works at low power as well as the battery bank is discharged for a long time, and the SOC of battery bank decreases to $73 \%$ after $5000 \mathrm{~s}$.

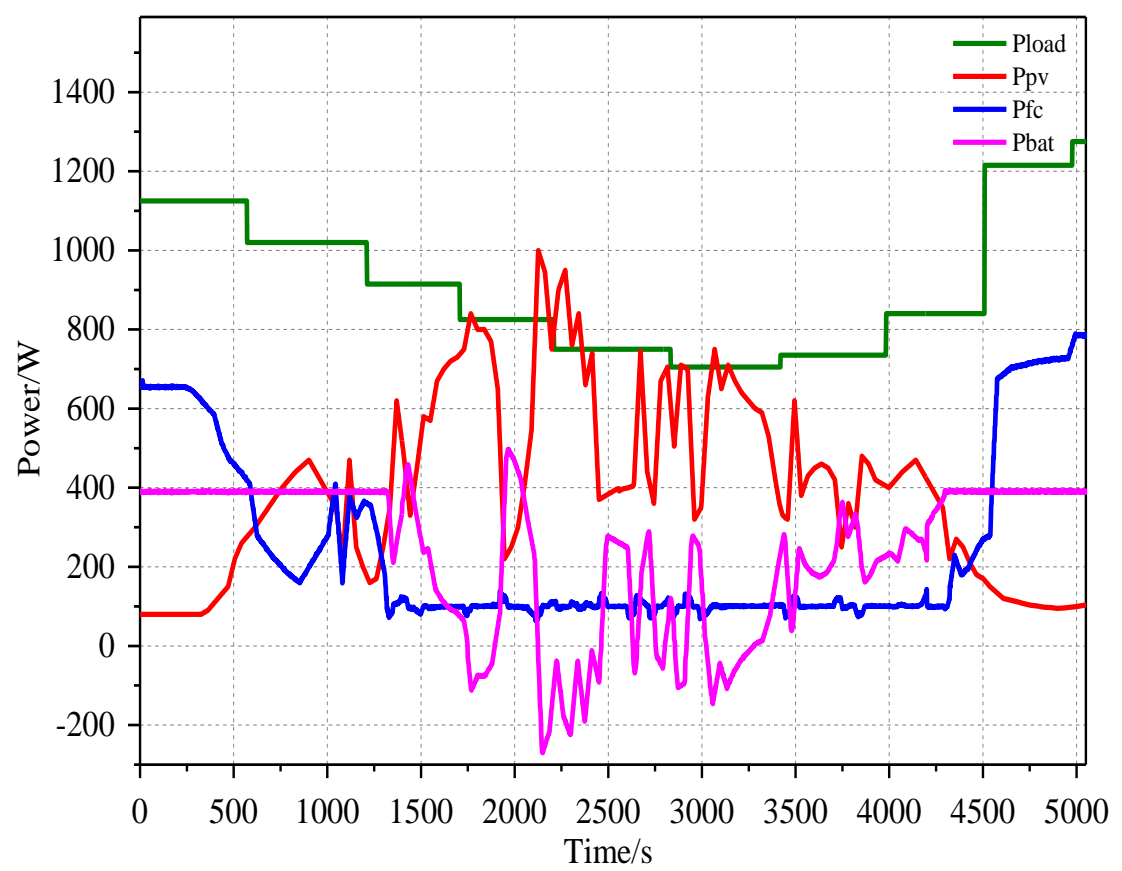

Figure 13. Power flow of the DC microgrid with initial SOC at $95 \%$. 


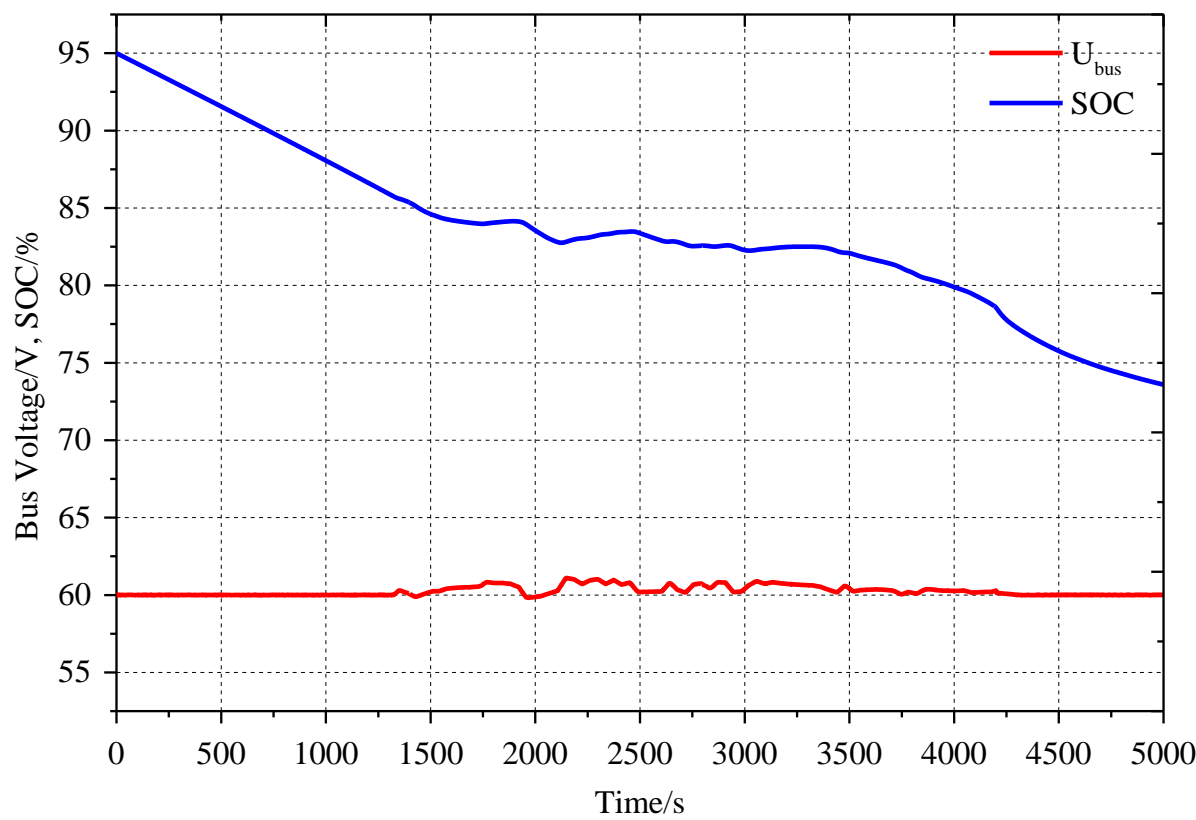

Figure 14. The bus voltage and SOC of the battery bank in Case III.

The control performance of the proposed strategy of DC microgrid is summarized in Table 4 . In Case I (low SOC state), PV array and FC generation system provide the mostly demand power for load and charge the battery simultaneously, thus the SOC of battery bank increases from $25 \%$ to $34 \%$ and the overall hydrogen consumption of the FC generation system is comparatively larger, about $109.3 \mathrm{~g}$. In Case II (normal SOC state), the FC system operates mostly at the optimum power point to achieve a higher system efficiency, and the battery is controlled to keep its SOC in a suitable range. It turns out that the overall average efficiency of the FC generation system is up to $56.6 \%$ within the whole working period. In Case III (high SOC state), the battery bank works in discharging mode since its SOC is in a higher level and FC system works mostly at the minimum power point, resulting in the lowest overall hydrogen consumption $(35.6 \mathrm{~g})$ and the SOC of battery decreases to a suitable lower level. To sum up, the power flow of the distributed generations can be coordinately controlled based on the efficient optimal energy management strategy under different operating state.

Table 4. The control performance of DC microgrid in each case.

\begin{tabular}{cccc}
\hline Performance Index & Case I & Case II & Case III \\
\hline Average Efficiency of FC Generation System (\%) & $54.0 \%$ & $56.6 \%$ & $50.5 \%$ \\
Hydrogen Consumption of FC Generation System (g) & 109.3 & 84.5 & 35.6 \\
SOC of Battery Bank ( $\%)$ & $25 \% \rightarrow 34 \%$ & $60 \% \rightarrow 61.5 \%$ & $95 \% \rightarrow 73 \%$ \\
\hline
\end{tabular}

\section{Conclusions}

In this paper, an efficient optimal energy management strategy based on multiple operating states has been proposed as a solution to the PV/FC/energy storage DC microgrid. In this microgrid platform, the primary and auxiliary sources are PV array and FC generation system respectively, moreover the battery bank works as an energy storage device. The energy management system and the converters' controller are built within the LabVIEW environment and executed with DAQ card and RS232 of PC.

In this energy management system, the control objectives are longer life of the distributed generations, higher efficiency of distributed generators and lower system cost, and maintaining the battery SOC in a suitable range, the coordinated control of multiple objectives is considered adequately in the efficient optimal energy management strategy as well. In the normal operating condition, the PV 
array keeps working in MPPT mode mostly to make full use of renewable energy; the battery bank is controlled by the energy management strategy to realize the reasonable power distribution between the FC and battery, and the FC system works at constant voltage mode to maintain the stability of the DC bus voltage and the balance of the power flow. The efficient optimal energy management system controls the power flow between the FC generation system and the battery bank in different operating condition, which has been divided into 13 operating states depending on the SOC of battery bank, the system's net demand power, and the optimal working points of distributed generations.

The performance of the proposed energy management strategy is evaluated in the PV/FC/energy storage DC microgrid under different initial battery SOC states. The results show that this strategy can control different distributed generations with power equilibrium, and that it can achieve optimal control of the DC microgrid system.

Acknowledgments: The authors would like to thank the reviewers for their helpful suggestions. This work was supported by National Natural Science Foundation of China $(61473238,51407146)$, National Key Technology R\&D Program (2014BAG08B01), and Sichuan Provincial Youth Science and Technology Fund (2015JQ0016), Project supported by the Fok Ying-Tong Education Foundation for Young Teachers in the Higher Education Institutions of China (142027).

Author Contributions: Ying Han and Qi Li proposed the energy management strategy; Ying Han performed the experiments; Weirong Chen and Qi Li analyzed the data; Ying Han, Weirong Chen, and Qi Li wrote the paper.

Conflicts of Interest: The authors declare no conflict of interest.

\section{References}

1. Nejabatkhah, F.; Li, Y.W. Overview of power management strategies of hybrid AC/DC microgrid. IEEE Trans. Power Electron. 2014, 30, 7072-7089. [CrossRef]

2. Marzband, M.; Yousefnejad, E.; Sumper, A. Real time experimental implementation of optimum energy management system in standalone Microgrid by using multi-layer ant colony optimization. Int. J. Electr. Power Energy Syst. 2016, 75, 265-274. [CrossRef]

3. Li, C.; Vasquez, J.C.; Guerrero, J.M. Convergence analysis of distributed control for operation cost minimization of droop controlled DC microgrid based on multiagent. In Proceedings of the 31st Annual IEEE Applied Power Electronics Conference and Exposition, Long Beach, CA, USA, 20-24 March 2016.

4. Ding, M.; Zhang, Y.Y.; Mao, M.Q. Key technologies for microgrids-A review. In Proceedings of the International Conference on Sustainable Power Generation and Supply, Nanjing, China, 6-7 April 2009.

5. Mehrasa, M.; Pouresmaeil, E.; Mehrjerdi, H.; Jørgensen, B.N.; Catalão, J.P.S. Control technique for enhancing the stable operation of distributed generation units within a microgrid. Energy Convers. Manag. 2015, 97, 362-373. [CrossRef]

6. Vigneysh, T.; Kumarappan, N. Autonomous operation and control of photovoltaic/solid oxide fuel cell/battery energy storage based microgrid using fuzzy logic controller. Int. J. Hydrog. Energy 2015, 41, 1877-1891. [CrossRef]

7. Mehrasa, M.; Pouresmaeil, E.; Jrgensen, B.N.; Catalão, J.P.S. A control plan for the stable operation of microgrid during the grid-connected and islanding modes. Electr. Power Syst. Res. 2015, 129, 10-22. [CrossRef]

8. Angelino, R.; Bracale, A.; Carpinelli, G.; Mangoni, M.; Proto, D. A fuel cell-based dispersed generation system providing local and system ancillary services through power electronic interfaces. Renew. Energy J. 2011, 36, 2312-2323. [CrossRef]

9. Lonkar, M.; Ponnaluri, S. An overview of DC microgrid operation and control. In Proceedings of the Renewable Energy Congress, Sousse, Tunisia, 24-26 March 2015.

10. Chen, Y.K.; Wu, Y.C.; Song, C.C.; Chen, Y.S. Design and implementation of energy management system with fuzzy control for DC microgrid systems. IEEE Trans. Power Electron. 2013, 28, 1563-1570. [CrossRef]

11. Kakigano, H.; Miura, Y.; Ise, T. Low-Voltage bipolar-type DC microgrid for super high quality distribution. IEEE Trans. Power Electron. 2011, 25, 3066-3075. [CrossRef]

12. Kwasinski, A. Quantitative evaluation of DC microgrids availability: Effects of system architecture and converter topology design choices. IEEE Trans. Power Electron. 2011, 26, 835-851. [CrossRef] 
13. Bracale, A.; Caramia, P.; Carpinelli, G.; Mancini, E.; Mottola, F. Optimal control strategy of a DC micro grid. Int. J. Electr. Power Energy Syst. 2015, 67, 25-38. [CrossRef]

14. Liu, Y.; Pratt, A.; Kumar, P.; Xu, M.; Lee, F.C. 390 V input VRM for high efficiency server power architecture. In Proceedings of the 22nd IEEE Applied Power Electronics Conference and Exposition, Anaheim, CA, USA, 25 February-1 March 2007.

15. Schulz, W. ETSI standards and guides for efficient powering of telecommunication and Datacom. In Proceedings of the 29th International Telecommunications Energy Conference, Rome, Italy, 30 September-4 October 2007.

16. Du, Y.; Zhou, X.H.; Bai, S.Z.; Lukic, S.; Huang, A. Review of non-isolated bi-directional DC-DC converters for plug-in hybrid electric vehicle charge station application at municipal parking decks. In Proceedings of the 25th IEEE Applied Power Electronics Conference and Exposition, Palm Springs, CA, USA, 21-25 February 2010.

17. Marzband, M.; Parhizi, N.; Savaghebi, M.; Guerrero, J.M. Distributed smart decision-making for a multimicrogrid system based on a hierarchical interactive architecture. IEEE Trans. Energy Convers. 2015, 31, 637-648. [CrossRef]

18. Sun, K.; Zhang, L.; Xing, Y. A distributed control strategy based on DC bus signaling for modular photovoltaic generation systems with battery energy storage. IEEE Trans. Power Electron. 2011, 26, 3032-3045. [CrossRef]

19. Sechilariu, M.; Wang, B.C.; Locment, F.; Jouglet, A. DC microgrid power flow optimization by multi-layer supervision control. Design and experimental validation. Energy Convers. Manag. 2014, 82, 1-10. [CrossRef]

20. Bracale, A.; Angelino, R.; Carpinelli, G.; Mangoni, M.; Proto, D. Dispersed generation units providing system ancillary services in distribution networks by a centralized control. IET Renew. Power Gener. 2011, 5, 311-321. [CrossRef]

21. Valverde, L.; Rosa, F.; Real, A.J.D.; Arce, A.; Bordons, C. Modeling, simulation and experimental set-up of a renewable hydrogen-based domestic microgrid. Int. J. Hydrog. Energy. 2013, 38, 11672-11684. [CrossRef]

22. Thounthong, P.; Chunkag, V.; Sethakul, P.; Sikkabut, S.; Pierfederici, S.; Davat, B. Energy management of fuel cell/solar cell/supercapacitor hybrid power source. J. Power Sources 2011, 196, 313-324. [CrossRef]

23. Brka, A.; Kothapalli, G.; Al-Abdeli, Y.M. Predictive power management strategies for stand-alone hydrogen systems: Lab-scale validation. Int. J. Hydrog. Energy 2015, 40, 9907-9916. [CrossRef]

24. Amin; Bambang, R.T.; Rohman, A.S.; Dronkers, C.J.; Ortega, R.; Sasongko, A. Energy management of fuel cell/battery/supercapacitor hybrid power sources using model predictive control. IEEE Trans. Ind. Electron. 2014, 10, 1992-2002.

25. Valverde, L.; Bordons, C.; Rosa, F. Integration of fuel cell technologies in renewable energy based microgrids optimizing operational costs and durability. IEEE Trans. Ind. Electron. 2015, 63, 167-177. [CrossRef]

26. Bizon, N.; Radut, M.; Oproescu, M. Energy control strategies for the fuel cell hybrid power source under unknown load profile. Energy 2015, 86, 31-41. [CrossRef]

27. Marzband, M.; Ghazimirsaeid, S.S.; Uppal, H.; Fernando, T. A real-time evaluation of energy management systems for smart hybrid home Microgrids. Electr. Power Syst. Res. 2017, 143, 624-633. [CrossRef]

28. Han, J.; Charpentier, J.F.; Tang, T. An energy management system of a fuel cell/battery hybrid boat. Energies 2014, 7, 2799-2820. [CrossRef]

29. Zhou, W.; Yang, H.X.; Fang, Z.H. A novel model for photovoltaic array performance prediction. Appl. Energy 2007, 84, 1187-1198. [CrossRef]

(C) 2017 by the authors; licensee MDPI, Basel, Switzerland. This article is an open access article distributed under the terms and conditions of the Creative Commons Attribution (CC BY) license (http:/ / creativecommons.org/licenses/by/4.0/). 